\title{
PENGARUH MODEL PEMBELAJARAN JOYFULL LEARNING TERHADAP KEAKTIFAN DAN HASIL BELAJAR SISWA PADA MATERI PERTIDAKSAMAAN LINEAR SATU VARIABEL KELAS VII-I SMPN 1 KEDUNGWARU TULUNGAGUNG
}

\author{
Nur Azizah ${ }^{1}$, Ainun Jariyah ${ }^{2}$, Windy Arianti ${ }^{3}$, Nurrishma S. $\mathbf{H}^{4}$. \\ Jurusan Tadris Matematika, FTIK, IAIN Tulungagung \\ E-mail: nurazizah.na517@ gmail.com, jariyahainun225@gmail.com, \\ windymaya099@gmail.com, piscorinrishma@gmail.com
}

\begin{abstract}
Abstrak
Penelitian ini membahas tentang pengaruh penerapan model pembelajaran joyfull learning yang bertujuan untuk mengetahui taraf signifikan pengaruh penggunaan model pembelajaran joyfull learning terhadap keaktifan dan hasil belajar matematika siswa pada materi sistem pertidaksamaan linear satu variabel kelas VII-I SMPN 1 Kedungwaru Tulungagung. Metode yang digunakan dalam penelitian ini adalah metode penelitian eksperimen dengan desain dan teknik pengambilan data menggunakan pretest-postest only control group design. Dalam pengambilan sampel dalam penelitian ini menggunakan teknik cluster random sampling. Untuk mencapai tujuan yang dimaksud, teknik penelitian ini terdiri dari melakukan tes sebelum penerapan pembelajaran joyfull learning (pretest) dan tes sesudah pembelajaran joyfull learning (posttest) kepada satu kelas yang terpilih sebagai subjek penelitian. Hasil penelitian ini menunjukkan bahwa penerapan model pembelajaran joyfull learning dapat meningkatkan keaktifan dan hasil belajar siswa, karena pembelajarannya menyenangkan dan membuat siswa berperan aktif dalam proses pembelajaran, sehingga dapat disimpulkan bahwa penggunaan model pembelajaran joyfull learning memberikanpengaruh terhadap keaktifan siswa dan hasil belajar matematika siswa pada materi sistem pertidaksamaan linear satu variabel kelas VII-I di SMPN 1 Kedungwaru Tulungagung.
\end{abstract}

Kata Kunci: Joyfull Learning, Hasil Belajar, Pengaruh, Keaktifan.

\section{PENDAHULUAN}

Peran matematika sangat penting dalam kehidupan sehari-hari untuk sekarang ini, karena matematika banyak diperlukan dalam melaksanakan aktivitas di segala bidang kehidupan, karena peran matematika tersebut maka pembelajaran matematika di sekolah harus dapat diajarkan kepada siswa dengan konsep yang baik. Pada proses pembelajaran dalam menerapkan konsep yang baik dan mudah dipahami serta 43 TRANSFORMASI - Jurnal Pendidikan Matematika \& Matematika

Vol. 3 No. 1 Edisi Bulan Juni Tahun 2019 ISSN: 2549-1164 
dapat memberikan rasa senang saat belajar agar siswa tidak mudah bosan, maka diperlukan model pembelajaran yang tepat. Jika guru tidak melakukan hal tersebut maka akibatnya terdapat kecenderungan penggunaan model pembelajaran yang bersifat monoton, yaitu guru menggunakan model yang hampir sama pada setiap kompetensi yang diajarkan (Rini, 2017).

Kesulitan belajar materi yang dialami oleh siswa disebabkan oleh beberapa faktor antara lain metode dan pendekatan yang digunakan oleh guru dalam menyampaikan materi pembelajaran kurang tepat, yang mengakibatkan siswa akan kurang aktif dalam proses pembelajaran berlangsung (Lestari, 2017). Seperti pada siswa kelas VII-I SMP Negeri 1 Kedungwaru masih kurang aktif dalam pembelajaran. Keaktifan siswa pada mata pelajaran matematika, berpengaruh pula terhadap prestasi belajar siswa. Oleh karena itu, diperlukan pendekatan pembelajaran yang melibatkan siswa secara intelektual dan emosional, sehingga siswa terlatih belajar secara aktif dan kreatif (Lestari, 2017). Sebagai guru atau seorang pendidik selain harus mengetahui apakah model pembelajaran itu tepat di gunakan bagi siswa yang kita ajar kita juga harus mengetahui apakah penggunaan model pembelajaran yang kita pilih efektif untuk meningkatkan keaktifan dan hasil belajar siswa.

Untuk mengatasi masalah kesulitan belajar seperti yang ada maka sebaiknya guru menelaah lagi metode yang akan digunakan pada materi yang hendak diajarkan. Metode yang digunakan hendaknya melibatkan rasa senang, bahagia, dan nyaman dari semua pihak yang terlibat dalam proses pembelajaran. Disini terdapat keterikatan cinta dan kasih sayang antara guru dan siswa maupun antar siswa, sehingga dalam proses belajar mengajar akan membuat masing-masing pihak berusaha memberikan yang terbaik untuk menyenangkan pihak lain. Guru akan berusaha secara optimal untuk memimpin kelas dengan cara yang paling menarik sedangkan siswa akan antusias dan berlomba-lomba ikut aktif ambil bagian dalam setiap kegiatan (Anonim, 2017).

Guru dapat menggunakan metode pembelajaran Joyfull Learning dalam mengatasi masalah di atas. Penggunaan metode Joyfull Learning merupakan 44 | TRANSFORMASI - Jurnal Pendidikan Matematika \& Matematika 
alternatif pendekatan yang dapat dilakukan untuk meningkatkan minat belajar yang menyenangkan sehingga keaktifan siswa meningkat, dan berakibat pada hasi belajar. Pembelajaran ini dapat diterapkan pada sekolah dasar dan sekolah menengah seperti di SMP Negeri 1 Kedungwaru yang menerapkan model Joyfull Learning, sehingga siswa lebih bersemangat dan bergembira dalam belajar. Guru juga akan dengan mudah menyampaikan materi yang hendak diajarkan.

Dengan menggunakan model pembelajaran Joyfull Learning bertujuan agar siswa lebih aktif dalam memperoleh informasi. Jika siswa aktif maka akan semakin mudah menerima segala sesuatu yang berkaitan dengan pembelajaran. Jika siswa semakin meningkat keaktivitasnya akan berdampak positif pula pada hasil belajarnya (Shen, dkk., 2008). Selain itu, metode Joyfull learning dapat menjadi alternatif dalam menciptakan pembelajaran yang monoton dan menjenuhkan tidak lagi monoton dan bahkan pembelajaran matematika akan lebih menyenangkan.

Matematika masih dianggap sulit, rumit dan tidak menarik di kalangan siswa. Padahal pada dasarnya dalam pembelajaran matematika diperlukan keterlibatan siswa dalam mempelajarinya. Dengan siswa yang aktif maka pembelajaran matematika akan lebih interaktif dan lebih menarik, sehingga pembelajaran akan menyenangkan. Jika suasana pembelajaran dan berkesan maka dapat menarik minat peserta didik untuk terlibat aktif, sehingga tujuan pembeajaran akan dapat terwujud secara maksimal serta akan meningkatkan hasil belajar (Shen, dkk., 2008).

Untuk melaksanakan pembelajaran juga dibuat perangkat pembelajaran, yang meliputi rencana pengajaran dengan menggunakan keterampilan proses, lembar observasi untuk mengetahui aktivitas dan kerjasama siswa dalam proses pelaksanaan proses pembelajaran. Tes hasil belajar untuk mengetahui keterampilan dan kemampuan siswa dalam memecahkan masalah dan tingkat keberhasilan dapat dilihat pada setiap akhir siklus (Lestari, 2017).

Tujuan penelitian ini yaitu untuk mengetahui pengaruh model pembelajaran joyfull learning terhadap keaktifan dan hasil belajar siswa pada materi pertidaksamaan linear satu variabel kelas VII-I SMPN 1 Kedungwaru Tulungagung. 45 | TRANSFORMASI - Jurnal Pendidikan Matematika \& Matematika Vol. 3 No. 1 Edisi Bulan Juni Tahun 2019 ISSN: 2549-1164 


\section{METODE PENELITIAN}

Penelitian ini merupakan penelitian dengan pendekatan kuantitatif, yaitu penelitian yang bertujuan untuk mengetahui besar pengaruh dari penggunaan suatu model pembelajaran Joyfull Learning terhadap keaktifan dan hasil belajar siswa. Subjek populasi pada penelitian ini adalah seluruh siswa kelas VII di SMPN 1 Kedungwaru, sedangkan sampelnya adalah siswa kelas VII-I SMPN 1 Kedungwaru dengan menggunakan model pembelajaran Joyfull Learning yang didalamnya terdapat dua tipe pembelajaran, yaitu NHT (Number Head Together) dan Snowball Throwing.

Instrumen pada penelitian ini adalah angket yang berupa lembar observasi. Teknik pengumpulan data pada penelitian ini adalah pre-test dan post-test yang dikerjakan secara mandiri oleh setiap siswa. Data yang diperoleh dari pre-test diambil sebelum menggunakan model pembelajaran Joyfull Learning, sedangkan hasil posttest diambil setelah penggunaan model pembelajaran Joyfull Learning. Bentuk soal yang digunakan adalah soal pilihan ganda dengan jumlah 5 soal pada setiap test, dimana setiap soalnya memiliki bobot nilai 20 .

Teknik analisis data yang digunakan, yaitu uji normalitas, uji t berpasangan, dan uji regresi. Uji normalitas dilakukan dengan menghitung apakah data tersebut berdistribusi normal atau tidak, uji t berpasangan dilakukan dengan cara menghitung selisih antara dua variabel dan menguji apakah selisih rata-rata tersebut bernilai nol, dan uji regresi dilakukan dengan cara menghitung berapa persen (\%) pengaruh dari metode yang digunakan.

\section{HASIL DAN PEMBAHASAN}

Penelitian dilakukan pada hari kamis tanggal 22 November 2018 dengan penelitian eksperimen yaitu penelitian secara langsung untuk mengetahui pengaruh pembelajaran Joyfull Learning terhadap hasil belajar siswa dan keaktifan siswa. Peneliti mengadakan kegiatan pembelajaran menggunakan satu kelas eksperimen yaitu kelas VII-I dengan materi Persamaan Linear Satu Variabel dan Pertidaksamaan 
Linear Satu Variabel pada pertemuan ke 4 dengan alokasi waktu 3 Jam Pelajaran yang dimulai dari jam 07.00-09.10.

Pelaksanaan pembelajaran selama eksperimen diawali dengan peneliti mereview materi sebelumnya dengan proses tanya jawab. Banyak siswa yang aktif dalam proses tersebut sekitar $40 \%$ dari total 25 siswa yang hadir dikarenakan banyak siswa yang izin saat itu membuat peneliti sedikit tidak terbebani dan membuat suasana lebih kondusif. Kebanyakan yang aktif adalah siswa perempunan dan ketika ditanyai apakah sudah membaca materi selanjutnya hanya 2 anak yang mengatakan sudah. Sebelum penyampaian materi awal peneliti membagikan pre-test untuk mengetahui seberapa besar pemahaman siswa dan hasil belajar siswa sebelum diberi perlakuan model pembelajaran Joyfull Learning.

Materi awal membahas tentang tanda pertidaksamaan kemudian dilanjutkan dengan mencari nilai $\mathrm{x}$ dengan cara menambah, mengurangi, mengalikan dan membagi kedua ruas dengan bilangan yang sama, apabila membagi dan mengalikan dengan bilangan real positif maka tanda pertidaksamaan tetap bagitu pula jika mengalikan dan membagi dengan bilangan real negatif maka tanda pertidaksamaan akan berubah. Peneliti menuliskan beberapa rumus untuk mengingatkan beserta contoh soal yang dibahas secara bersama-sama. Siswa cukup aktif dalam proses pembelajaran tersebut tidak sedikit siswa yang berani bertanya dalam kesulitan belajar saat itu. Kemudian peneliti memberikan penjelasan materi tentang HP pertidaksamaan linear satu variabel meskipun hanya sedikit memberi umpan kepada mereka tidak sedikit yang langsung tanggap dalam proses pembelajaran tersebut. Setelah materi peneliti memberikan 1 soal untuk pemahaman materi dan dikerjakan secara individu tidak lupa si peneliti berkeliling memantau proses pembelajaran langsung (Direct Interaction) kemudian peneliti menawarkan kepada siswa yang ingin menyampaikan hasil penyelesaiannya, lalu peneliti mulai menerapkan pembelajaran Joyfull Learning yang selanjutnya yaitu pembelajaran yang menyenangakan dimana ada 2 tipe didalamnya yaitu NHT dan Snowball Throwing dimana setiap siswa kebagian nomor kepala dengan nomor yang berbeda untuk memudahkan peneliti memanggilnya dan 47 | TRANSFORMASI - Jurnal Pendidikan Matematika \& Matematika

Vol. 3 No. 1 Edisi Bulan Juni Tahun 2019 ISSN: 2549-1164 
setiap siswa terbagi 1 lembar kertas. Sebenarnya tipe NHT banyak diterapkan dalam pembelajaran kooperatif tetapi tidak memungkiri juga dapat diterapkan dalam pembelajaran langsung (Direct Interaction). Peneliti mulai menjelaskan aturan permainannya dan diharapkan siswa tetap dapat kondusif. Ternyata tidak sesuai dengan harapan ketika pelaksanaan Snowball Throwing banyak siswa yang ramai sehingga menyulitkan peneliti untuk mengkondisikan kelas. Terlihat juga siswa sangat senang tidak ada rasa membosankan seperti pembelajaran biasanya yang begitu-begitu saja dan membuat siswa yang pendiam menjadi lebih aktif karena merasakan kesenangan dalam proses pembelajaran tersebut. Kemudian peneliti menyuruh kembali ke tempat duduk kemudian menyuruh mengerjakan secara mendiri tidak lepas dari pembelajaran langsung peneliti tetap melakukan bimbingan secara langsung. Peneliti memanggil 2 nomor kepala secara acak yang kemudian menyuruh siswa mempresentasikan hasil dan yang membuat soal berhak mengoreksinya. Setelah semua merasa agak menurun semangatnya peneliti mengadakan Ice Breaking untuk penutupan. Tidak lupa untuk kesimpulan, peneliti memberikan tawaran siapa yang ingin menyimpulkan di depan kelas dan terdapat 3 anak yang bersedia tapi peneliti hanya menginginkan 1 anak saja. Untuk tahap yang terakhir yaitu peneliti menyebar post-test yang berisi 5 butir soal tentang pembahasan tadi kemudian mengumpulkannya di depan kelas. Untuk penutupan, peneliti memberikan Reward untuk siswa yang berani dan lebih aktif dalam pembelajaran, tidak lupa peneliti juga memberikan kesimpulan dan motivasi penguat di akhir pembelajaran.

Dari pengamatan peneliti peningkatan keaktifan siswa sudah terlihat cukup baik. Rasa suka terhadap pelajaran matematika juga meningkat dapat diketahui dari berbagai faktor antara lain mungkin karena perasaan siswa, pembelajaran yang menyenangkan bahkan mungkin karena materinya yang cukup mudah. Data hasil penelitian eksperimen yang dilakukan dengan model Joyfull Learning menunjukkan ada perubahan yang signifikan dari hasil pre-test yaitu sebelum diberi perlakuan dengan hasil post-tes yaitu sesudah diberi perlakuan model Joyfull Learning hasilnya lebih baik dan memberikan dampak yang positif antara lain peningkatan hasil belajar, 48 | TRANSFORMASI - Jurnal Pendidikan Matematika \& Matematika 
siswa dapat membuat soal dan bertanggung jawab atas soal dan siswa merasa lebih menikmati proses pembelajaran tidak tegang bahkan menyenangkan.

Dari hasil data diatas juga telah diuji normalitas, t hubungan dan regresi bahwa ada pengaruh penerapan model Joyfull Learning terhadap pembelajaran pada materi persamaan linear satu variabel dan pertidaksamaan linear satu variabel dengan instrumen tes dan observasi yeng sudah dijalankan. Hasil perhitungan yang dapat peneliti sampaikan sebagai berikut :

1) Didapat perhitungan awal yaitu uji normalitas hasil data pre-test dan post-test dan hasilnya normalitas dapat dilihat dari hasil akhir dan grafik berbentuk lonceng.

2) Uji t berpasangan untuk menentukan apakah ada beda nilai sebelum dan sesudah diberi perlakuan.

3) Konstanta a (nilai ketetapan pre-test) $=27,08$ dan koefisien $b=0,98$ sehingga persamaan regresi yang didapat adalah $\mathrm{Y}=27,08+0,98 \mathrm{x}$.

Kriteria pengujian hipotesis sebagai berikut :

1) Untuk kasus normalitas pre-test dan post-test.

$\mathrm{H}_{0} \quad$ : Data berasal dari populasi berdistribusi normal

$\mathrm{H}_{1} \quad$ : Data berasal dari populasi yang berdistribusi tidak normal (Pretes) dengan $\mathrm{M}=33,6$ dan $\mathrm{SD}=22,15$ didapat statistika hitung = 0,24 dan statistika tabel $=0,27$. Apabila statistika hitung $<$ statistika tabel maka terima H0.Dapat dilihat $0,24<0,27$ maka terima H0 yaitu data berasal dari populasi berdistribusi normal.

(post-tes) dengan $\mathrm{M}=60$ dan $\mathrm{SD}=33,66$ didapat ststistika hitung = 0,22 dan statistika tabel $=0,27$. Apabila statistika hitung $<$ statistika tabel maka terima $\mathrm{H}_{0}$. Dapat dilihat $0,22<0,27$ maka terima $\mathrm{H}_{0}$ yaitu data berasal dari populasi berdistribusi normal.

2) Untuk kasus uji t berpasangan dengan alasan model pembelajaran berpengaruh jika ada beda nilai sebelum dan sesudah penggunaan model pembelajaran joyfull. 
Hipotesis : Ada beda hasil belajar sebelum dan sesudah penggunaan model pembelajaran Joyfull Learning.

$$
\begin{aligned}
& \mathrm{H}_{0}=M_{1}=M_{2} \\
& \mathrm{H}_{1}=M_{1} \neq M 2
\end{aligned}
$$

Dengan $t_{\text {hitung }}=-5,02$ dan $t_{\text {tabel }}=2,06$ dengan $n-2$.Sehingga Tolak $H_{0}$ didapat $M_{1}$ $\neq \mathrm{M}_{2}$ yaitu ada beda hasil belajar sebelum dan sesudah pengaruh pengunaan model pembelajaran Joyfull Learning. Penggunaan model pembelajaran Joyfull Learning berpengaruh terhadap hasil belajar materi SPLSV dan SPtLSV.

3) Untuk kasus regresi dan signifikan didapat $\mathrm{Y}=27,08+0,98 \mathrm{x}$.

$$
\begin{aligned}
& \mathrm{H}_{0}=\text { persamaan } \mathrm{Y}=27,08+0,98 \times \text { tidak signifikan } \\
& \mathrm{H}_{1}=\text { persamaan } \mathrm{Y}=27,08+0,98 \times \text { signifikan }
\end{aligned}
$$

$F_{\text {hitung }}=17,36$ dan $F_{\text {tabel }}=4,28$ jadi apabila $F_{\text {hitung }}>F_{\text {tabel }}$ yaitu 17,36>14,28 maka terima $\mathrm{H}_{0}$ yaitu persamaan $\mathrm{Y}=27,08+0,98 \times$ signifikan. Dengan relasi $=$ 0,64 dan nilai determinasi 0,409. Dapat disimpulkan besar faktor yang mempengaruhi hasil belajar sebesar 40,9\%.

Dari analisis data diatas dapat kita sebutkan bahwa hasil belajar sebelum dan sesudah mendapatkan hasil normalitas, begitu juga dari uji t hubungan yang menyebutkan ada beda hasil sebelum dan sesudah perlakuan dan yang terakhir terdapat kadar determinasi sebesar 40,9\% dan sangat signifikan.

Peningkatan hasil belajar dikatakan meningkat dikarenakan pada kelas yang diterapkan model Joyfull Learning dan pembelajaran langsung mengakibatkan hasil belajar siswa meningkat dan keaktifan siswa pun juga meningkat. Peneliti selain melakukan pre-test dan post-test juga melakukan observasi untuk mengetahui perubahan-perubahan yang terjadi. Banyak hal positif yang terjadi mungkin juga karena mood mereka yang lagi baik tetapi juga ada siswa yang sangat hiperaktif larilari dikelas bahkan terkadang mengganggu temannya tetapi tidak dapat dipandang sebelah bahkan dia sudah dapat menyelesaikan satu soal dan berani presentasi di depan kelas. Ketika mereka mendapatkan model pembelajaran baru mereka masih bertanya-tanya dan rasa ingin tahu tinggi bagaimana proses selanjutnya. Langkah 50 $\mid$ TRANSFORMASI - Jurnal Pendidikan Matematika \& Matematika 
demi langkah mereka pun merasakan perbedaan dengan pembelajaran yang biasanya dan merasa lebih asik ucap salah satu siswa dalam kelas saat ditanya. Tidak lupa pemberian reward juga membuat siswa tertarik dan berebut ingin mendapatkan. Itulah salah satu strategi dari peneliti agar siswa tidak jenuh dengan model pembelajaran yang itu saja, siswa lebih banyak berekspresi membuat soal dan bertanggung jawab, siswa juga lebih aktif dan berebut menjawab.

Berdasarkan hasil penelitian sebelumnya terbukti bahwa pembelajaran joyfull learning dapat menigkatkan hasil belajar dan keaktifan siswa di kelas. Disamping itu dalam metode ini dapat menumbuhkan tanggug jawab, kejujuran, persaingan secara sehat, dan keberanian. Hasil belajar meningkat dan dikatakan berhasil jika ada peningkatan skor yang diperoleh siswa, dapat dilihat dalam tes yang diberikan Susanto (2013). Pada metode joyfull learning ini tidak mudah diterapkan kepada jumlah siswa yang banyak dan bukan pekerjaan yang mudah untuk menyatukan kemampuan individual siswa.

\section{KESIMPULAN DAN SARAN}

Dari pembahasan yang telah dipaparkan, dapat disimpulkan bahwa penggunaan model pembelajaran Joyfull Learning dalam pembelajaran matematika kelas VII-I di SMPN 1 Kedungwaru Tulungagung terdapat pengaruh yang signifikan pada keaktifan dan hasil belajar siswa, yaitu dapat dilihat dari meningkatnya keaktifan siswa ketika pembelajaran di kelas, dan meningkatnya prestasi belajar matematika siswa. Taraf signifikansi pengaruh penggunaan model pembelajaran Joyfull Learning di SMPN 1 Kedungwaru Tulungagung pada kelas VII-I adalah kuat ditunjukkan dalam hasil penelitian bahwa taraf signifikan sebesar $40,9 \%$

\section{REFERENSI}

Anonim. (2017). Pendekatan Joyful Learning pada Proses Pembelajaran di Sekolah Pendekatan Joyful Learning pada Proses Pembelajaran di Sekolah Dasar, (July). 
Lestari, S. (2017). Penerapan Pembelajaran Group Investigation untuk Meningkatkan Prestasi dan Keaktifan Siswa Materi Statistika. Journal of Medives, I(2), 150-157. Retrieved from http://e-journal.ikipveteran.ac.id/index.php/matematika

Rini, J. (2017). Problematika Penerapan Model Pembelajaran Kooperatif Tipe Numbered Head Together (Nht) dan Alternatif Solusinya. Journal of Medives, l(2), 112-122. Retrieved from http://e-journal.ikipveteran.ac.id/index.php/matematika

Shen, L., Farid, H., \& Mcpeek, M. A. (2008). [ No Title ]. Evolution, 1-14.

Susanto, Ahmad. (2013). Teori Belajar dan Pembelajaran di Sekolah Dasar. (akarta: Prenadamedia Group. 